\title{
Defining geoexchange extraction rates in the same geological environment for different borehole geometry settings - Pilot results from the HAPPEN - HORIZON 2020 project
}

Rudarsko-geološko-naftni zbornik

(The Mining-Geology-Petroleum Engineering Bulletin) UDC: $622.1: 627.8$

DOI: $10.17794 / \operatorname{rgn} .2021 .3 \cdot 7$

Original scientific paper

\section{Tomislav Kurevija'; Marija Macenić'; Tea Sabolić́; ${ }^{1}$ Dalibor Jovanovićc}

1,2,3 Faculty of Mining, Geology and Petroleum Engineering; 10000 Zagreb, Croatia

${ }^{4}$ Istrian Regional Energy Agency; Rudarska 1; 52220 Labin
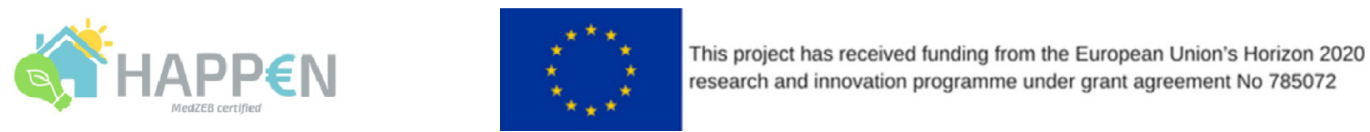

\begin{abstract}
Kindergarten Grdelin in the city of Buzet, Istria, Croatia, was chosen to undergo a deep retrofit of the current thermotechnical system, as a part of the HORIZON 2020 HAPPEN project ${ }^{1}$. The existing shallow spiral heat exchanger field is insufficient to cover heating loads of the building. Therefore, additional BHEs were drilled and completed to determine optimal borehole heat exchanger type within the same geological environment. Four BHEs, either single $U$ ( $1 \mathrm{I} U)$ or double $\mathrm{U}(2 \mathrm{U})$, with different geometrical setting and depth were tested: BHE-1 (50 m, 2U DN32 ribbed), BHE-2 (75 m, $2 \mathrm{U} \mathrm{DN} 40$ ribbed), BHE-3 (100 m, 2U DN32 smooth) and BHE-4 (150 m, 1 U DN45 ribbed). A thermal response test (TRT) was performed to obtain the ground thermal properties. Furthermore, synthetic TRT curves were calculated to describe temperature response in the case of different heat pulses. This was done to determine heat extraction rates and the capacity of each BHE type, according to EN14511 norm. It was established that the BHE-4 is the optimal design for heating and cooling purposes on the selected site due to positive impact of the geothermal gradient, higher initial borehole temperature and a positive effect of the ribbed inner wall.
\end{abstract}

\section{Keywords:}

borehole heat exchanger, geological environment, geothermal gradient, heat extraction rates.

\section{Introduction}

The use of shallow geothermal energy is promoted in the European Union as one of the energy sources to exploit in order to reduce the carbon footprint and increase the use of renewable energy sources (Directive (EU) 2018/2001). By 2018, the estimated total heating and cooling installed capacity of shallow geothermal sources with closed geoexchange in the Republic of Croatia was 4.5 $\mathrm{MW}_{\mathrm{t}}$ (Macenić et al., 2018). The overall length of all installed borehole heat exchangers (BHE) is at least $55 \mathrm{~km}$ at the end of 2020. Additionally, the use of groundwater in open type heat pump systems is currently at a capacity of $13.7 \mathrm{MW}_{\mathrm{t}}$ (Kapuralić et al., 2018).

The number of the ground source heat pump (GSHP) system installations are steadily on the rise (Lund and Toth, 2020). The energy analysis shows that, compared to the air source heat pump (ASHP), GSHP systems are more efficient and consume less energy to heat or cool a building (Ozgener et al., 2007; Li et al., 2014). The de-

Corresponding author: Tomislav Kurevija tkurevi@rgn.hr sign of the borehole heat exchanger has a significant influence on the efficiency of the GSHP (Fang et al., 2017). When it comes to BHEs design, there are three main types: single $\mathrm{U}(1 \mathrm{U})$, double $\mathrm{U}(2 \mathrm{U})$ and coaxial. Bouhacina et al. (2015) performed a numerical analysis on the influence of a ribbed (finned) and smooth inner pipe, $1 \mathrm{U}$ DN32, on the BHE performance, with the same depth $(50 \mathrm{~m})$ and thermogeological setting. Even though the temperature response for a smooth and ribbed pipe were of a similar shape, the values obtained were in favour of the ribbed pipe. The analysis showed that the temperature response is more favourable during the recovery period in the case of the ribbed pipe, resulting in better heat extraction/rejection. Fang et al. (2017) studied the influence of different $1 \mathrm{U}$ and $2 \mathrm{U}$ designs on the GSHP efficiency. The study analysed 4 different BHE designs - 1U DN25, 1U DN32, 2U DN25 and 2U DN32 $\mathrm{mm}$, with different distances between the corresponding $\mathrm{U}$ tubes as well as between the boreholes. The thermal

\footnotetext{
1 This paper reflects only the view of the authors and the Commission is not responsible for any use that may be made of the information it contains.
} 
conductivity was also varied in order to determine the influence of different geological settings. The main findings showed that $2 \mathrm{U}$ design is preferred over $1 \mathrm{U}-$ in order to satisfy the building's heating/cooling loads, the total drilling depth is shorter by around $15 \%$ when using 2U BHE DN25 in comparison to $1 \mathrm{U}$ DN32. This is due to the $2 \mathrm{U}$ pipes having a larger surface area where the heat transfer is taking place. Furthermore, favourable thermal conductivity of the soil will lead to shorter BHEs, as well as a larger borehole and pipe spacing. With an increase in the borehole spacing, the thermal interference between boreholes is minimized (Fang et al., 2017; Kurevija et al., 2012). From an economical point of view, the $U$ design is also advantageous, except in the case of very low drilling cost (Fang et al., 2017). Bae et al. (2019) compared the thermal performance of 4 different pipe types - 1U HDPE (high density polyethylene), 1U HDPE-nano (improved thermal conductivity using nano-particles), 1U HDPE spiral fin (ribbed) and coaxial pipe, set in the same geological conditions and with the same depth. The results showed that when it comes to the pipe material, the HDPE-nano type shows an increase of average effective thermal conductivity of around 4\% and HDPE spiral fin around 13\%, compared to a regular HDPE type. It was concluded that the higher values were due to an increase of pipe thermal conductivity and higher convective heat transfer coefficient respectively. The effective borehole thermal resistance values were similar for the $1 \mathrm{U}$ types of BHE, with ribbed type having the lowest value due to improved convective heat transfer coefficient. While investigating energy efficiency of the GSHP system by observing the effects of the variable fluid flow at the source side, Zarrella et al. (2017) analysed the effect of three different BHE types, 1U, 2U and coaxial, on GSHP performance. Thermogeological properties and investigating depth was the same for all three cases. Numerical analysis showed that the temperature response was similar for the $1 \mathrm{U}$ and $2 \mathrm{U}$ pipes. Kurevija et al. (2019) compared the results of thermal response test performed on 2U DN32 smooth pipe, 2U DN32 ribbed pipe and 1U DN45 ribbed pipe, set in the same geological environment and with the same depth of $110 \mathrm{~m}$. The results showed that $2 \mathrm{U}$ ribbed pipe had higher heat extraction/rejection rates compared to $2 \mathrm{U}$ smooth and $1 \mathrm{U}$ DN45 ribbed. Likewise, 1U DN45 ribbed pipe showed somewhat better performance than the smooth $2 \mathrm{U}$ DN32 layout. The research also suggested better performance of the 1U DN45 type in the case of deeper boreholes, due to the favourable values of the pressure drop, compared to $2 \mathrm{U}$ pipes. Beside the classic circular pipe cross-section, there are other designs being investigated in order to improve BHE efficiency, such as oval shaped cross-section pipes (Serageldin et al., 2020) or elliptical (Jahanbin, 2020).

This paper addresses scientific research related to heat extraction rates of the different types of BHE in the same geological environment. The research idea was re- alized through the HORIZON 2020 project (HAPPEN Holistic AProach and Platform for the deep renovation of the med residential built Environment - Grant agreement ID:785072). The Croatian project partner was IRENA - Istrian Regional Energy Agency, from the city of Labin. The overall project objective is to stimulate the market uptake of deep retrofitting of buildings, with special regard to the Mediterranean area and to the residential built stock, by tackling major bottlenecks, such as the fragmentation of the supply chain, the lack of transparency and of the perceived reliability of the interventions, of adequate financial support mechanisms, of integration among the relevant aspects connected to retrofitting, the low return on investments, or the lack of a retrofit approach clearly tailored for the Mediterranean environments (https://cordis.europa.eu/project/id/ 785072).

One of the pilot projects was carried out in the city of Buzet in Istria, at the location of Kindergarten Grdelin. In order to successfully adapt the Kindergarten Grdelin building to MEDzeb standards (Mediterranean Zero Energy Building), it was determined that the existing thermotechnical system needs to be subjected to significant adaptation. The initial system consisted of two independent components - a centralized heating system and a local, multi-unit low efficiency cooling system (split AC). The centralized heating system is partially based on the use of renewable energy sources with insignificant impact on a buildings' primary energy consumption - low enthalpy geothermal and solar energy. On the flip side, the $84 \mathrm{~kW}$ inverter heat pump is the system's central unit. Even though the heat pump is a reversible model, within the current system it cannot be used as the cold water source since its primary circuit heat exchanger is situated in six $27 \mathrm{~m}^{3}$ underground water storage tanks, which are used as heat rejection for a $60 \mathrm{~m}^{2}$ solar thermal collector plant. The kindergarten's heating energy distribution system is based on high temperature radiators in a low to mid temperature regime $\left(30^{\circ} \mathrm{C}-45^{\circ} \mathrm{C}\right.$, depending on external conditions). The system only partially uses a renewable geothermal energy source, as the primary circuit is undersized in relation to the installed heat pump capacity, so the system is currently a bivalent one with $38 \mathrm{~kW}$ electric heaters serving as backup unit. In order to remedy this, two main interventions were needed:

1. the development of an upgraded thermotechnical and electric installation system main design (with the addition of centralized chilled water distribution system via fan coils);

2. upscaling of the heat pump primary circuit capacity via the addition of a separate BHE field that can act as an independent heat extraction source.

Upscaling of the primary geothermal circuit was completed in 2019. In order to determine the optimal borehole heat exchanger characteristics for the cooling system in a Mediterranean climate and local geological conditions, test boreholes had different characteristic 
(depth, pipe diameter and surface characteristics). On the basis of data acquired via the Thermal Response Test (TRT), an optimal borehole heat exchanger was chosen, and it represents the basis for the geothermal heat exchanger field, installed by the city of Buzet. The total output power of the geothermal field is $45 \mathrm{~kW}_{\mathrm{t}}$ and it is within the required parameters (the building requirements peak at around $60 \mathrm{~kW}_{\mathrm{t}}$ ). With the coefficient of performance (COP) of the heat pump around 4.5, this output alone would satisfy both the heating and the cooling needs of the building.

Scientific merit, as part of the project objective and results, is to test and compare heat extraction rates of the different borehole geometrical settings and depth in the same geological environment. Such a procedure would show which geoexchange system design has the comparative thermodynamic advantage to be implemented in larger scale projects on the Istrian peninsula in the future. The research geoexchange borehole field, as part of the pilot project, consists of five vertical boreholes with different piping geometry and depth, and such designs are commonly found in practice all over the EU. Scientific research on the drilled boreholes was carried out by the Thermal Response Test apparatus during March/April of 2019.

\section{Mathematical models related to the study}

The thermal response test (TRT) is a common method used to determine soil and rock thermal properties, in relatively shallow surroundings. The TRT is based on observing temperature response of the circulating fluid, as a function of time and constant load rejection into the ground. The method itself is analogue to the flow test used in well testing - a common procedure in petroleum engineering to determine the productivity of a reservoir. The analogy of methods stems from the similarity of Fourier's and Darcy's solution to the differential diffusion equation of heat conduction in solids and fluid flow in porous media, respectively, in an infinite surrounding (Fourier, 1822; Chiasson, 2016).

Ingersoll and Zobel (1913) expressed Fourier's diffusion equation with partial differential equation of radial heat flow as:

$$
\alpha\left[\frac{\partial^{2} T}{\partial r^{2}}+\frac{1}{r} \frac{\partial T}{\partial r}+\frac{1}{r^{2}} \frac{\partial^{2} T}{\partial \phi^{2}}+\frac{\partial^{2} T}{\partial z^{2}}\right]=\frac{\partial T}{\partial t}
$$

where:

$$
\begin{aligned}
& r \text { - radial coordinate, } \\
& T \text { - temperature, }\left({ }^{\circ} \mathrm{C}\right), \\
& \alpha \text { - thermal diffusivity, }\left(\mathrm{m}^{2} / \mathrm{s}\right), \\
& t \text { - time, }(\mathrm{s}), \\
& z \text { - height axis, } \\
& \phi \text { - azimuthal coordinate. }
\end{aligned}
$$

Within the analytical methods used to solve Fourier's diffusion equation, there are two main methods - line and cylindrical source models. Infinite and finite line source models are two-line source models used for the analysis for the paper. Both line source models assume that the BHEs are located in an infinite, homogeneous and isotropic porous medium, and describe radial heat transfer. However, the models differ in boundary conditions taken into account when solving for a heat diffusion equation.

\subsection{Infinite line source - ILS}

The infinite line source model presumes that the borehole diameter dimension is negligible when compared to the length dimension of the borehole, i.e. the borehole is presumed to be an infinite line $\left(\partial^{2} T / \partial z^{2}=0\right)$, and radial heat extraction or rejection is observed. The solution of this model, which describes the temperature change as a function of radius and time, was given by Carslaw and Jaeger (1959). The solution for the case of heat rejection (the case of thermal response test - TRT) is then written as:

$$
T\left(r_{b}, t\right)_{r e j}=T_{i}+\frac{q^{\prime}}{4 \pi \lambda}\left(E i\left(\frac{r_{b}^{2}}{4 \alpha t}\right)\right)
$$

where:

$T\left(r_{b}, t\right)_{r e j}$ - temperature in function of radius and time in the case of heat rejection, $\left({ }^{\circ} \mathrm{C}\right)$,

$T_{i} \quad$ - initial borehole temperature, $\left({ }^{\circ} \mathrm{C}\right)$,

$q^{\prime} \quad-$ heat power per meter of a borehole, $(\mathrm{W} / \mathrm{m})$,

$\lambda-$ thermal conductivity, $\left(\mathrm{W} / \mathrm{m}^{\circ} \mathrm{C}\right)$,

$\mathrm{Ei}$ - exponential integral,

$r_{b} \quad$ - borehole radius, $(\mathrm{m})$,

$\alpha \quad-$ thermal diffusivity, $\left(\mathrm{m}^{2} / \mathrm{s}\right)$.

The term $r_{b}^{2} / 4 \alpha t$ is the variable of the exponential integral. Equation 2 mathematically describes the ideal thermal response of the BHE during TRT, with a constant heat load, as a function of exponential integral (Eskilson, 1987; Lee, 1982; Matthews and Russell, 1967). When the variable is $<0.01$, the exponential integral can be replaced with the function of natural logarithm $-E i(-x) \cong-\ln \left(e^{\gamma} x\right) \cong \ln (1 / x)-0.5772$. Equation 2 , when solving for heat rejection (rej), can then be written as (Kurevija et al., 2018a):

$$
\begin{gathered}
T\left(r_{b}, t\right)_{r e j}=T_{i}-\frac{q^{\prime}}{4 \pi \lambda} \ln \left(\frac{e^{\gamma} r_{b}^{2}}{4 \alpha t}\right)= \\
\quad=T_{i}-\frac{q^{\prime}}{4 \pi \lambda}\left(\ln \frac{\alpha t}{r_{b}^{2}}-0,80907\right)
\end{gathered}
$$

where:

$e-$ Euler number (2.7183),

$\gamma$ - Euler's constant $(\gamma=0.5772)$.

The standard procedure to determine effective thermal conductivity, as part of the thermal response test analysis, is carried out by plotting temperature and time in semi-logarithm diagram. The dependence of the slope 
of the line $(\kappa)$ in a semi-logarithmic diagram to thermal conductivity and heat power is then (Gehlin, 2002):

$$
\lambda=\frac{q^{\prime}}{4 \pi \kappa}
$$

where:

$$
\kappa \text {-slope of the line. }
$$

Calculation of the temperature response of the BHE has to account for near-borehole formation damage, which is defined as the borehole thermal resistance. In petroleum engineering, this parameter is called the skin factor and it describes the formation damage due to which there is resistance to the fluid flow into the well. In thermogeology, the borehole thermal resistance is equivalent to the term skin factor. It describes the thermal resistance to the heat flow from the surrounding ground toward the circulating fluid in the BHE. The grout mixture, used to fill the space between the pipes and the borehole wall, can cause thermal resistance since grouts usually have lower thermal conductivity values when compared to the surrounding rock. In order to reduce the skin effect, enhanced thermal grout can be used (Kurevija et al., 2017). Furthermore, thermal resistance is also caused by low thermal conductivity of the polyethylene pipes, as well as pipe configuration, fluid and flow properties. The value of the thermal borehole resistance can be expressed via temperature difference of the working fluid and temperature at the borehole wall (Lee, 1982; Kurevija et al., 2018a):

$$
\Delta T_{\text {skin }}=s\left(\frac{q^{\prime}}{2 \pi \lambda}\right)=R_{b}^{\prime} \cdot q^{\prime}
$$

where:

$\Delta T_{\text {skin }}$ - temperature drop/rise due to skin effect, $\left({ }^{\circ} \mathrm{C}\right)$, $s{ }^{\text {skin }}$ - skin factor,

$R_{b}^{\prime} \quad$ - equivalent borehole thermal resistance, $\left({ }^{\circ} \mathrm{C}\right.$ $\mathrm{m} / \mathrm{W})$.

The average working fluid temperature in the borehole heat exchanger, when skin is included, is then expressed as (Kurevija et al., 2018a):

$$
\begin{aligned}
& T=T_{i}-\frac{q^{\prime}}{4 \pi \lambda}\left(\ln \left(\frac{e^{\gamma} r_{b}^{2}}{4 \alpha t}\right)\right)+\Delta T_{\text {skin }}= \\
& =T_{i}-\frac{q^{\prime}}{4 \pi \lambda}\left(\ln \left(\frac{r_{b}^{2}}{\alpha t}\right)-0,80907-2 s\right)
\end{aligned}
$$

The skin factor in thermogeology is then expressed as (Kurevija et al., 2018b):

where:

$$
s=\frac{1}{2} \ln \left(\frac{e^{\gamma} r_{b}^{2}}{4 \alpha t_{p}}\right)-\frac{\left(T_{i}-T_{p}\right) 2 \pi \lambda}{q}
$$

$$
\begin{array}{cc}
T_{i}-T_{p}- & \text { temperature difference between initial tem- } \\
& \text { perature and temperature at the end of the } \\
& \text { power step, }\left({ }^{\circ} \mathrm{C}\right), \\
t_{p} & - \text { duration of the power step during semi- } \\
& \text { steady state, }(\mathrm{s}) .
\end{array}
$$

When it comes to determining thermal conductivity, it is necessary to determine the period after which semisteady state heat transfer occurs, i.e. the period of initial unsteady-state heat transfer. The common method which determines the start of this period, within which the thermal conductivity is determined, uses the value of the thermal diffusivity of the ground. This value is usually taken from literature, according to ground composition on the site location:

$$
t>\frac{5 r_{b}^{2}}{\alpha}
$$

Since the thermal diffusivity value is not a measured one, this method of determining the period of the semisteady state, can cause an up to $20 \%$ error. Using the authors' novel derivation curve (Kurevija et al., 2018a) is a more precise method, and it is also often used in well testing in petroleum engineering. The method consists of observing the increase of the temperature, in constant time step as a function of time duration of the test, where $y$ represents borehole fluid temperature and $x$ the TRT elapsed time (Kurevija et al., 2018a):

$$
\left(\frac{d y}{d x}\right)_{A}=\frac{\left(\frac{y_{1}}{x_{1}} x_{2}+\frac{y_{2}}{x_{2}} x_{1}\right)}{\left(x_{1}+x_{2}\right)}
$$

where:

$x$ - TRT elapsed time,

$y$ - borehole fluid temperature.

Initially, temperature change in the time interval is high. However, after a while, temperature change for the same time interval is dampened, and the period of semisteady state heat transfer is assumed when temperature change is $0.25{ }^{\circ} \mathrm{C} / 10 \mathrm{~min}$, or less (Kurevija et al., 2018a).

\subsection{Finite line source - FLS}

The finite line source (FLS) model takes the real length of the borehole heat exchanger into account, unlike the infinite line source model. The FLS model is commonly used when boundary conditions are not met to use the ILS model (shorter time period of testing and shorter boreholes). Based on initial and boundary conditions, Cleasseon and Eskilson (1987) provided a solution for temperature at the borehole wall, by using the so-called g-function:

$$
T\left(r_{b}, t\right)=T_{i} \pm \frac{q^{\prime}}{2 \pi \lambda} g\left(\frac{t}{t_{s}}, \frac{r}{H}\right)
$$

where:

$g$ - Eskilson's g-function,

$t_{s}$ - time at which steady-state heat transfer occurs (s),

$H$ - borehole depth (m). 
Where the g-function is defined as:

$$
g\left(\frac{t}{t_{s}}, \frac{r}{H}\right)= \begin{cases}\ln \left(\frac{H}{2 r}\right) & , t>t_{s} \\ \ln \left(\frac{H}{2 r}\right)+\frac{1}{2} \ln \left(\frac{t}{t_{s}}\right) & , \frac{5 r^{2}}{\alpha}<t<t_{s}\end{cases}
$$

The average temperature in the BHE, in the case of heat rejection (rej), is then defined as:

$$
T_{f}(t)_{r e j}=T_{i}+\frac{q^{\prime}}{2 \pi \lambda} g\left(\frac{t}{t_{s}}, \frac{r}{H}\right)+\Delta T_{s k i n}
$$

and in the case of heat extraction (ext):

$$
T_{f}(t)_{e x t}=T_{i}-\frac{q^{\prime}}{2 \pi \lambda} g\left(\frac{t}{t_{s}}, \frac{r}{H}\right)+\Delta T_{\text {skin }}
$$

where:

$$
T_{f}(t) \text { - average fluid temperature in the BHE. }
$$

In order to model borehole heat exchangers, usually to cover variable heat loads throughout heating or cooling seasons, it is important to determine the temperature response of a working fluid. Variable heat loads are susceptible to yearly, monthly, daily and hourly change and are dependent on climate conditions. Temperature response is then, among other parameters, dependent on heat load change over time. In order to take heat loads into account, it is necessary to apply a given heat load, $q^{\prime}$, to its respective time span. In calculations of temperature response in case of variable heat loads, superimposing is applied. In the case of several different heat loads, each heat load is superimposed on the previous one, with the first heat load being applied to the entire time interval, $q_{1}^{\prime}=Q_{1}$ (Chiasson, 2016; Eskilson, 1987). The next heat load is superimposed on the previous one, $Q_{2}^{\prime}=q_{2}^{\prime}-q_{1}^{\prime}$, and so on. In the case of three different heat loads, where $q_{1}^{\prime}>q_{2}^{\prime}>q_{3}^{\prime}$, the average temperature of a working fluid in BHE would be determined as:

- first time interval, $q_{1}^{\prime}$ :

$$
T_{f}(t)=T_{i}+\left[\left(\frac{q_{1}^{\prime}}{2 \pi \lambda}\right) \cdot g_{t_{1}}\right]+\Delta T_{\text {skin } 1}
$$

- second time interval, $q_{1}^{\prime}>q_{2}^{\prime}$ :

$T_{f}(t)_{\text {avg }}=T_{i}+\left(\frac{1}{2 \pi \lambda}\right)\left[\left(q_{1}^{\prime} \cdot g_{t_{1}}\right)-\left(-q_{2}^{\prime}+q_{1}^{\prime}\right) \cdot g_{t_{2}-t_{1}}\right]+\Delta T_{\text {skin } 2}$

- third time interval, $q_{1}^{\prime}>q_{2}^{\prime}>q_{3}^{\prime}$

$$
\begin{gathered}
T_{f}(t)_{\text {avg }}=T_{i}+\left(\frac{1}{2 \pi \lambda}\right)\left[\left(q_{1}^{\prime} \cdot g_{t_{1}}\right)-\right. \\
\left.-\left(\left(-q_{2}^{\prime}+q_{1}^{\prime}\right) \cdot g_{t_{2}-t_{1}}\right)-\left(\left(-q_{3}^{\prime}+q_{2}^{\prime}\right) \cdot g_{t_{3}-t_{2}}\right)\right]-\Delta T_{\text {skin } 3}
\end{gathered}
$$

This method is applied to mathematically describe the Thermal Response Step Test (TRST). When performing the TRST, the first heat load is applied until a stable temperature response is attained or a steady-state heat flow. After the stabilized first temperature response, the heat load is changed and maintained until the temperature response is obtained again. This procedure can be repeated three to four times, with the recommendation that the highest heat load is two times higher than the lowest one. When analysing the data obtained with the TRST empirical method, which takes into account different heat pulses, linear approximation can be applied for each heat load when steady-state is achieved. Figure 1 shows the principle of conducting the thermal response step test. Kurevija et al. (2019) showed that the measured temperature response data can be fitted using the FLS relations. The FLS method in this paper was applied to fit measured data for the first step and to simulate thermal response in the case of additional two or three steps, with lower heat power pulses, thus describing thermal response with synthetic curves.

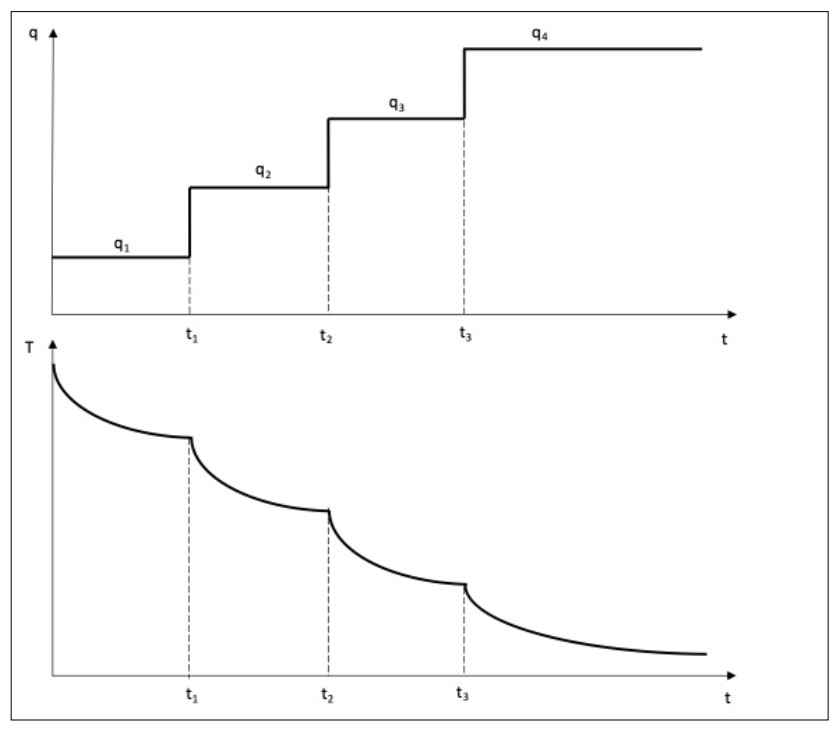

Figure 1: The principle of the thermal response step test, with different heat loads and respective temperature response

Sometimes, in the case of higher heat load, it would take a long time to achieve steady-state heat transfer. Therefore, more commonly pseudo-steady state point is used, as an approximation of the steady-state, i.e. reverse step test, in which case the heat loads are decreased from the highest load to the lowest. The thermal response step test is used to obtain the exact heat exchange rate of BHE $(\mathrm{W} / \mathrm{m})$ in relation to entering source temperature (EST). The application of the step test in thermogeology gives information on the BHE working fluid in bivalent systems, where the geothermal system runs on maximal peak power for a longer period of time. The TRST analysis is necessary to design minimal allowed steady-state 
inlet temperatures from the BHE field, without the risk of additionally cooling the ground in time.

\section{Experimental Site Setting}

\subsection{Geological setting of the location}

The research area is located in the town of Buzet (Istria County) in the Republic of Croatia. From a geological standpoint, large areas of Istria County are comprised of clastic sediments, known as Eocene clastic sediments and flysch. These sediments are found on the surface, in the north parts (between Momjan and Buzet, and between Buje and Oprtlje), in the central area (Pazin Basin) and in the southeast (area of Plomin and Labin basins) parts of the county. Lithologically, this unit is comprised of marl, sandstone, breccia, breccia conglomerate, and more rarely, limestone can be found. Even though the Eocene clastic sediments (usually with limestone sedimentation characteristics) are not of typical flysch sequence of those in the Alps, they do have some characteristics of flysch sediments, such as rhythmic interbedding of gravely-sandy-silty sediments, pronounced grain gradation, sharp contact of sandstone and marl sediments and instances of oriented sediment textures and bioglyphs. Marls are the most representative lithotype of these Eocene clastic sediments, when observing the thickness as well as the frequency of appearance. These marls contain between $23-77 \% \mathrm{CaCO}_{3}$, which is usually of microfossil origin. Depending on pelite siliclatic material and the percentage of $\mathrm{CaC}_{3}$ clay marl, mudstone, marl rich with calcite and rarely clayey limestone can be distinguished. Figure 2 shows the location of the experimental site in the town of Buzet and the geological setting. During the drilling process, there were no obtained core samples.
However, on all the boreholes, drill bits were monitored and collected. The entire drilling column consisted of gray, low-saturated marl.

\subsection{Borehole heat exchanger setting}

Thermal conductivity and heat extraction rate of vertical borehole heat exchangers were determined for heating and cooling purposes of Kindergarten Grdelin in Buzet. At the location, 5 boreholes of different depth were drilled and completed with different heat exchangers. Completion was done with pipes with different diameters (DN32, DN40 and DN45) and different internal pipe configuration (smooth or ribbed inner wall). This was done in order to test the influence of geothermal gradient and thermal conductivity on heat extraction rates of each of the usually used pipe configuration, in the same geological environment. Pipes with ribbed inner walls generally show better heat extraction results when compared to pipes with smooth inner walls (Bouhacina et al., 2015; Acuña, 2010). A pipe with a ribbed inner wall provides better turbulent fluid flow, which in effect decreases thermal borehole resistance, and in turn, better heat transfer between the ground and BHE pipes is achieved. On the other hand, for larger diameter of pipes (like DN45), thermal resistance can be somewhat higher since the thickness of the plastic wall is larger than in smaller pipes (like DN32). Additionally, hydraulic properties, i.e. pressure drop, can also be of significance when deciding on the pipe type (Kurevija and Strpić, 2018). For example, in the case of classic $2 U$ DN 32 pipe, pressure drop is higher than in the case of $1 \mathrm{U}$ DN45 pipe, for the same fluid flow conditions, effectively meaning that DN45 ribbed pipe has better hydraulic properties than classic 2U DN32 pipes (Kurevija et al.,

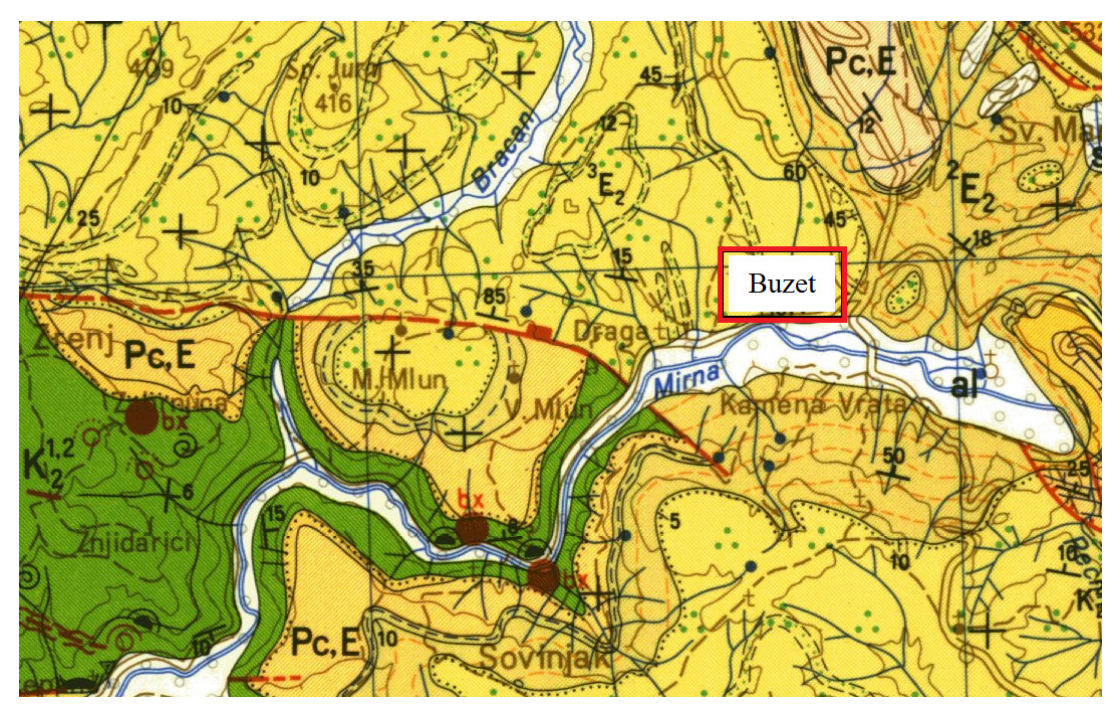

Figure 2: Detailed geological setting and experimental site location (The Geological Survey of Slovenia, 1969). Legend for geology map: al - alluvial deposits; ${ }^{2} \mathbf{E}_{2}$ - marls with scares layers of sandstone; ${ }^{3} \mathbf{E}_{2}-$ marls, sandstone, breccia, nummulitic breccia and limestone alterations; $\mathbf{K}_{2}^{1,2}-$ limestone with layers of dolomite; Pc,E - nummulitic limestone 

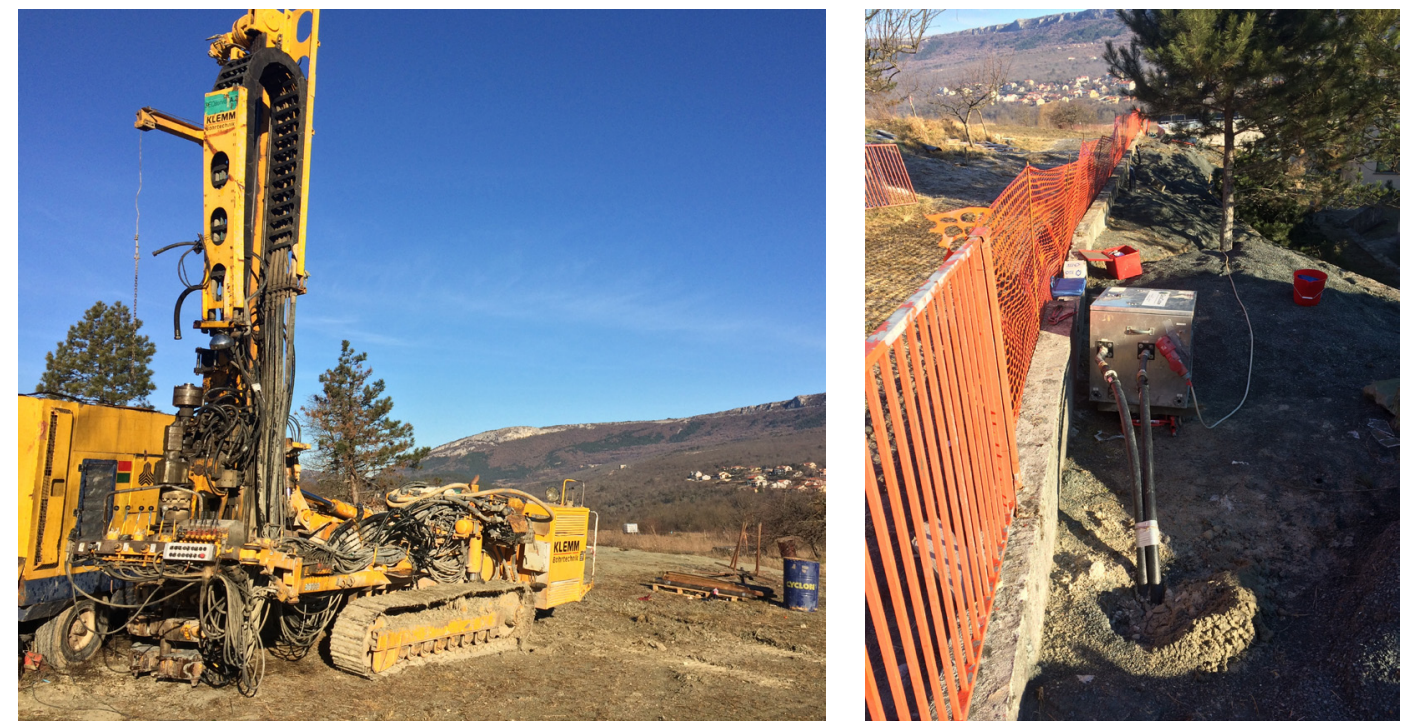

Figure 3: left) Experimental test site - drilling operations; right) Thermal response test equipment during testing

Table 1: Tested borehole heat exchanger properties

\begin{tabular}{|l|c|c|c|c|}
\hline & Heat exchanger type & Inner wall type & Borehole depth, m & Pipe diameter, mm \\
\hline BHE-1 2U DN32 50m & 2U & ribbed, 5mm spacing & 50 & 32 \\
\hline BHE-2 2U DN4075m & 2U & ribbed, 5mm spacing & 75 & 40 \\
\hline BHE-3 2U DN32 100m & 2U & smooth & 100 & 32 \\
\hline BHE-4 ${ }^{1 \mathrm{U} \text { DN45 } 150 \mathrm{~m}}$ & 1U & ribbed, 5mm spacing & 150 & 45 \\
\hline
\end{tabular}

2019). This means that heat transfer will be better in the case of a ribbed pipe, since transitional and turbulent fluid flow will be achieved at lower fluid flow rates, i.e. convective heat transfer coefficient is improved (Bae et al., 2019). With ribbed pipes, there is a lower possibility that the fluid flow will fall into laminar flow regime, which increases the thermal resistance value. Lower pressure drop also implies that the circulation pump will consume less energy, and in effect the seasonal coefficient of performance (SCOP) will have a better value. At the test site, each borehole was drilled with a $152 \mathrm{~mm}$ diameter and grouted with the mixture of bentonite $(60 \%)$ and cement $(40 \%)$ with water. Such a grout mixture has a thermal conductivity of approximately $1 \mathrm{~W} /$ $\mathrm{m}^{\circ} \mathrm{C}$ (ASHRAE, 1995). The distance between the boreholes was at least $6 \mathrm{~m}$, thus minimizing the thermal interference (Kurevija et al., 2012) between them and the new borehole field is arranged as $4 \times 1$. Figure 3 shows the drilling site and the thermal response test apparatus during measurement.

The experimental BHE field consisted of 5 boreholes with different depth and pipe completion. The first borehole, BHE-1, is $50 \mathrm{~m}$ deep. It is completed with a polyethylene (PE) 2U pipe with the technical specification DN32 SDR11 PE100 RC, with a ribbed inner wall. The BHE-2 borehole is $75 \mathrm{~m}$ deep and completed with a $2 \mathrm{U}$ DN40 SDR11 PE100 RC pipe, with a ribbed inner wall. The BHE-3 borehole is equipped with a $2 \mathrm{U}$ DN32
SDR11 PE100 RC, with a smooth inner wall, and is 100 $\mathrm{m}$ deep. The BHE-4 is equipped with a $1 \mathrm{U}$ DN45 SDR11 PE100 RC pipe, with a ribbed inner wall and is $150 \mathrm{~m}$ deep. The BHE-5 is completed with a $2 \mathrm{U}$ DN40 SDR 11 PE100 RC pipe with a smooth inner wall and is $75 \mathrm{~m}$ deep. In this paper, boreholes from BHE-1 to BHE-4 are analysed (see Table 1), while BHE-5, with a depth of 75 $\mathrm{m}$, was not tested due to clogging issues. The schematics of the tested boreholes, with geometrical characteristics are shown in Figure 4.

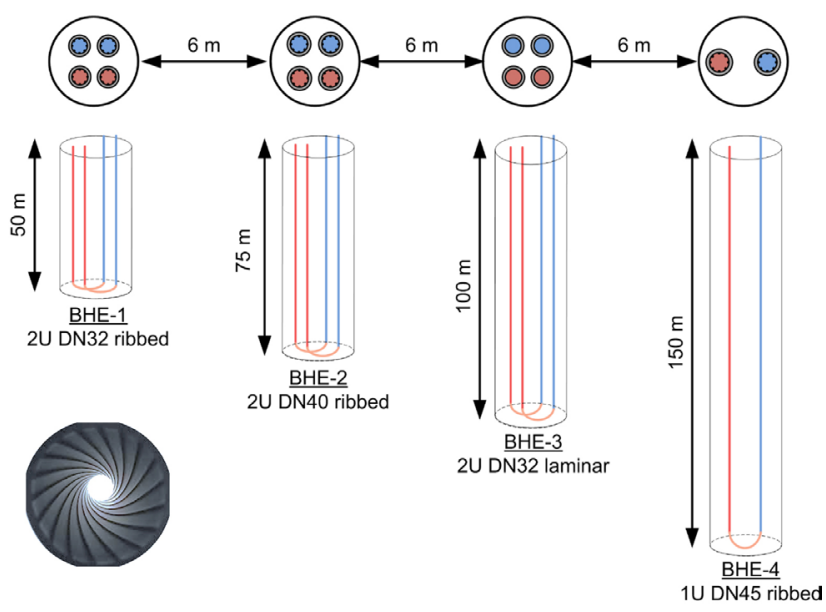

Figure 4: Schematics of the tested borehole heat exchangers on the location and cross-section of the installed pipes with Turbocollector $^{\mathrm{TM}}$ pipe interior 
The measuring was done with the TRT apparatus, with maximal heater power of $9.0 \mathrm{~kW}(3 * 2.5 \mathrm{~kW}+1 * 1$. $5 \mathrm{~kW})$, at $240 \mathrm{~V}$. The data was logged using Hobo U30 Series Data Logger; HOBOware Pro Software 2.4.0., in time intervals of 5 minutes. The performance of thermal response test in situ is defined by the International Ground Source Heat Pump Association (IGSHPA), where the duration of the TRT is set to at least 48 hours, because of common issues of variable voltage of the public power grid and temperature amplitudes due to outer temperature variations (day-night).

\section{Results}

Before turning on the electrical heaters, the initial borehole temperature was recorded for $20 \mathrm{~min}$ by circulating fluid through the BHE, using the TRT apparatus, in order to obtain the undisturbed ground temperature (static conditions) (Kurevija and Vulin, 2010). After that, the heaters were turned on and the temperature of the circulating fluid started to rise. The thermocouples measured the average inlet and outlet temperature of the circulating fluid. The rate at which the temperature rises is a function of the thermogeological parameters, power step $(\mathrm{W} / \mathrm{m})$ and borehole thermal resistance. Table 2 shows the recorded undisturbed temperatures and average TRT heat power $(\mathrm{W} / \mathrm{m})$ used for each borehole. According to Kappelmeyer and Haenel (1974), medium saturated clay and marl have an average thermal diffusivity of $0.060 \mathrm{~m}^{2} /$ day. This value was taken as representative for this geological environment. With a mean borehole radius of $0.075 \mathrm{~m}$ and a presumed thermal diffusivity, the time needed for stabilized heat transfer (i.e. achieving semi-steady state) and data interpretation was calculated at 12 hours, according to Equation 8 .

Table 2: Recorded initial borehole temperatures and average TRT heat power for four borehole heat exchangers

\begin{tabular}{|c|c|c|c|c|}
\hline & $\begin{array}{l}\text { Initial borehole } \\
\text { temperature, }{ }^{\circ} \mathrm{C}\end{array}$ & $\begin{array}{c}\text { Average TRT } \\
\text { heat power, } k W\end{array}$ & $\begin{array}{c}\text { Average TRT } \\
\text { heat power, W/m }\end{array}$ & $\begin{array}{l}\text { Standard deviation } \\
\text { of heat power, W/m }\end{array}$ \\
\hline BHE-12U DN32 50m ribbed & 14.5 & 2.523 & 50.5 & 0.52 \\
\hline BHE-2 2U DN40 75m ribbed & 14.4 & 4.734 & 63.1 & 0.56 \\
\hline BHE-3 2U DN32 100m smooth & 14.6 & 4.730 & 47.3 & 0.45 \\
\hline BHE-4 1 U DN45 150m ribbed & 15.5 & 5.985 & 39.9 & 0.40 \\
\hline
\end{tabular}

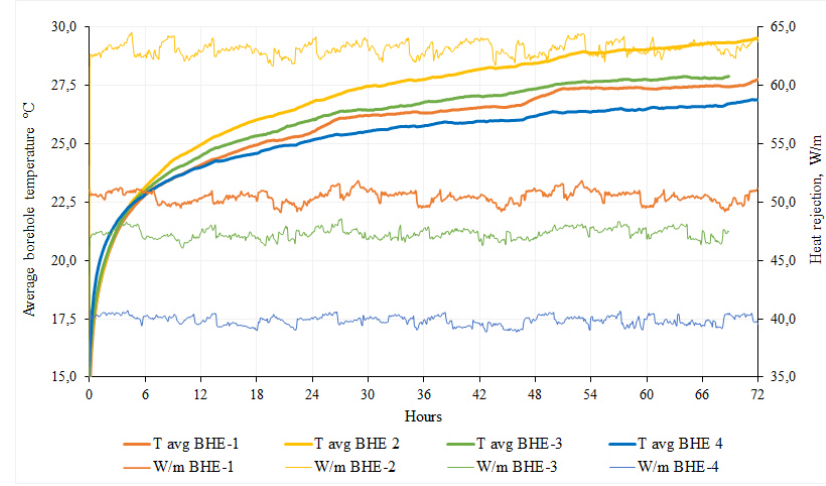

Figure 5: Recorded average circulating fluid temperatures and heat rejection for four tested BHE

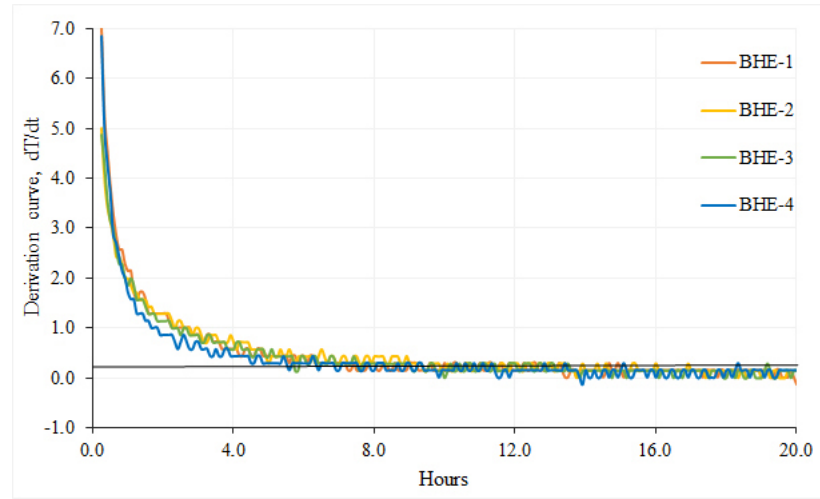

Figure 6: Determination of semi-steady heat flow period using the derivation curve method
Figure 5 shows the recorded average circulating fluid temperature and heat rejection recorded during the TR test, for each tested borehole. The TR test was conducted without any significant deviations (under 5\% voltage deviation) in the power supply for each tested BHE, indicating highly representative temperature curves. This can also be seen from the standard deviation of the power supply for each borehole from Table 2.

The average temperature of circulating fluid data as a function of natural logarithm of time, $\ln (\mathrm{t})$, is plotted on the diagram. The method of derivation curve (Equation 9) is used in order to specify the period after which the semi-steady state heat transfer occurs. As seen from Figure 6, the value of $\mathrm{dT} / \mathrm{dt}$ falls below the value of 0.25 ,

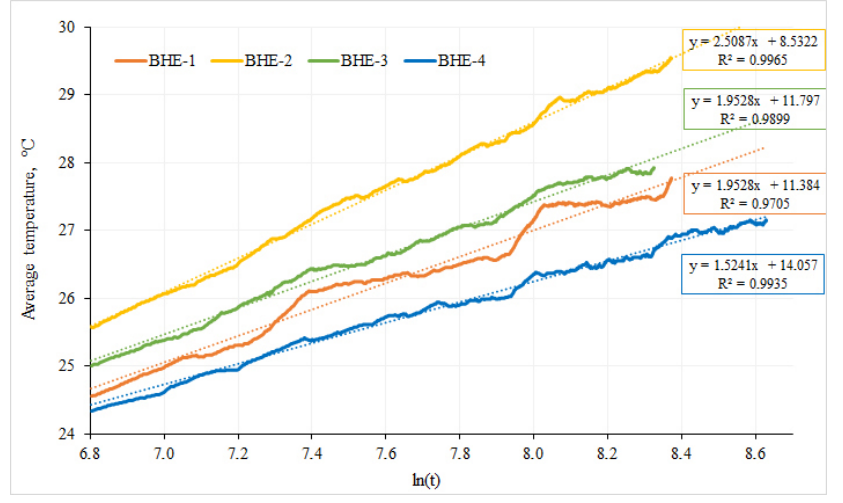

Figure 7: Determination of ground heat conductivity for the period 15-72 hr 

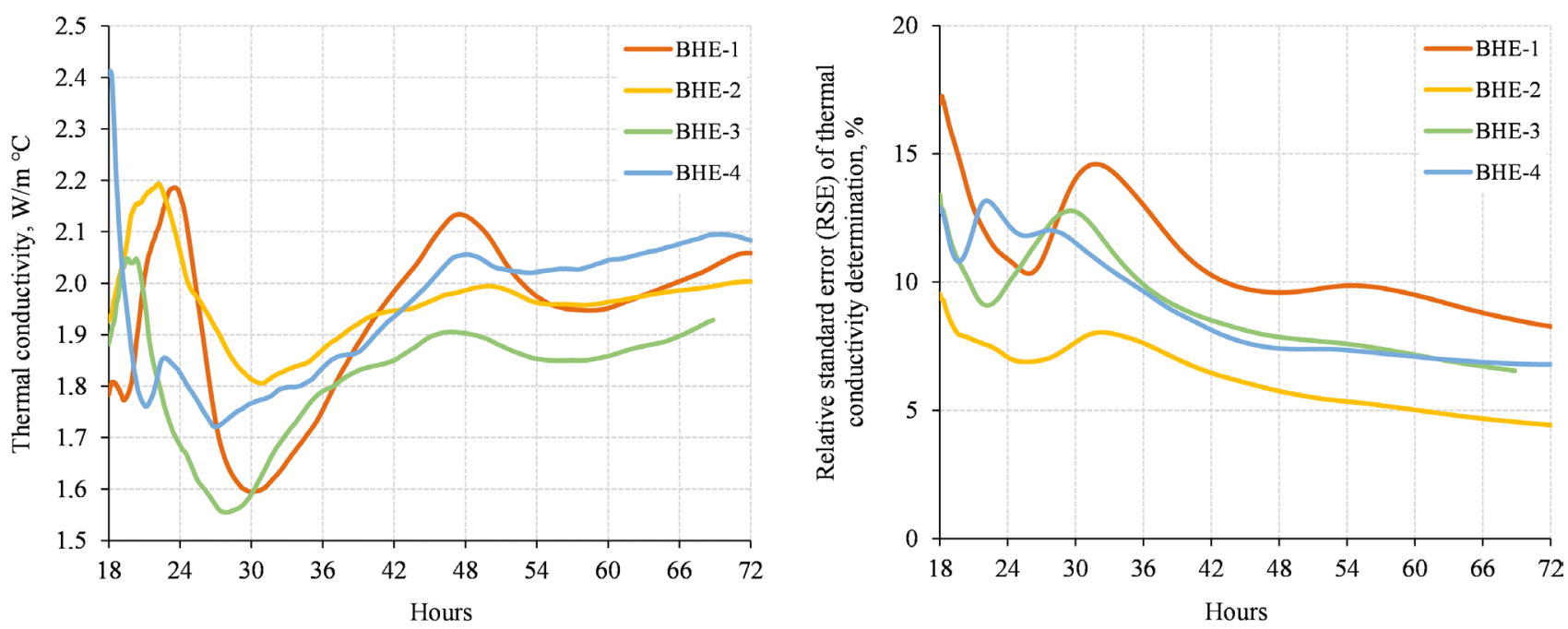

Figure 8: Variable transitory results of thermal conductivity from TRT for the period between 18-72 hours with falling relative standard error over time

after a period of 15 hours. This suggests a transition from unsteady state heat transfer to semi-steady state heat transfer, for all four exchangers. Data below the $15^{\text {th }}$ hour is disregarded and only data from the $15^{\text {th }}$ to $72^{\text {nd }}$ hour is plotted and used to determine the slope of the line, established as a straight-line portion between the average borehole temperature and the natural logarithm of time. Equation 4 is then used as a standard method of determining the effective ground thermal conductivity coefficient, as shown in Figure 7 for respective BHE. The calculated ground thermal conductivity is $2.06 \mathrm{~W} /$ $\mathrm{m}^{\circ} \mathrm{C}$ for BHE- $1,2.00 \mathrm{~W} / \mathrm{m}^{\circ} \mathrm{C}$ for BHE-2, $1.93 \mathrm{~W} / \mathrm{m}^{\circ} \mathrm{C}$ for BHE-3 and lastly, $2.08 \mathrm{~W} / \mathrm{m}^{\circ} \mathrm{C}$ for BHE-4.

Total duration of TRT is not strictly defined in any of the guidelines, i.e. only the minimum time is required in practical field testing, for example $48 \mathrm{hr}$. This always leads to a certain degree of analysis error since the final duration of the test is arbitrarily chosen by the TRT opera-
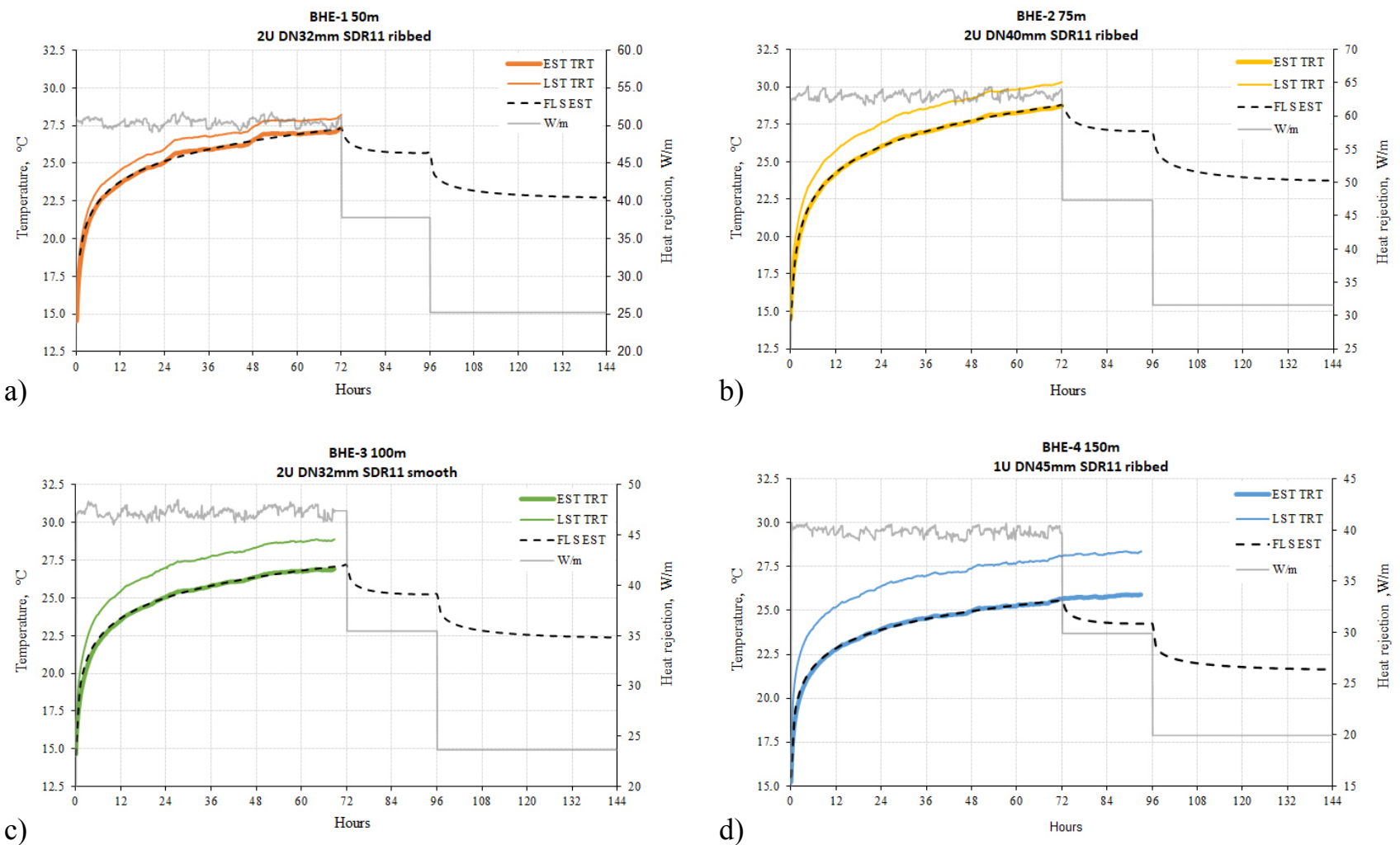

Figure 9: Recorded data and synthetic data fitted with finite line source (FLS) method (use of g-function) for four different pipe types: (a) 2U-pipe DN32 Ribbed; (b) 2U-pipe DN40 Ribbed; (c) 2U-pipe DN32 Smooth; (d) 1U-pipe DN45 Ribbed. Legend: EST - entering source temperature, LST - leaving source temperature; TRT - thermal response test 
Table 3: Data collected after performing Thermal Response test (TRT) and Thermal Response Step Test (TRST)

\begin{tabular}{|c|c|c|c|c|c|c|}
\hline $\begin{array}{l}\text { Heat } \\
\text { step }\end{array}$ & $\begin{array}{l}\text { BHE-12U DN32 50m } \\
\text { ribbed }\end{array}$ & TRT Time & Heat Power & Cooling Cycle & $\begin{array}{l}\text { Heating Cycle } \\
\text { (Inversed) }\end{array}$ & $\begin{array}{l}\text { Rejected Heat } \\
\text { TRT }\end{array}$ \\
\hline Step & Heat flow regime & $\mathrm{hr}$ & $\mathrm{W} / \mathrm{m}$ & $\mathrm{EST}^{\circ} \mathrm{C}$ & $\mathrm{EST}^{\circ} \mathrm{C}$ & $\mathrm{kWh}$ \\
\hline $1 \mathrm{a}$ & unsteady & 72.0 & 50.5 & 27.3 & 1.7 & 181.8 \\
\hline 1 & semi-steady state & 240.0 & 50.5 & 29.6 & -0.6 & - \\
\hline 2 & steady state & 24.0 & 37.8 & 25.7 & 3.3 & 0.0 \\
\hline 3 & steady state & 48.0 & 25.2 & 22.7 & 6.3 & 0.0 \\
\hline \multirow[t]{2}{*}{4} & initial conditions & 0 & 0.0 & 14.5 & 14.5 & 0.0 \\
\hline & $\begin{array}{l}\text { BHE-2 2U DN40 75m } \\
\text { ribbed }\end{array}$ & TRT Time & Heat Power & Cooling Cycle & $\begin{array}{l}\text { Heating Cycle } \\
\text { (Inversed) }\end{array}$ & $\begin{array}{l}\text { Rejected Heat } \\
\text { TRT }\end{array}$ \\
\hline Step & Heat flow regime & $\mathrm{hr}$ & $\mathrm{W} / \mathrm{m}$ & $\mathrm{EST}^{\circ} \mathrm{C}$ & $\mathrm{EST}^{\circ} \mathrm{C}$ & $\mathrm{kWh}$ \\
\hline $1 \mathrm{a}$ & unsteady & 72.0 & 63.1 & 28.7 & 0.1 & 340.9 \\
\hline 1 & semi-steady state & 240.0 & 63.1 & 31.8 & -3.0 & - \\
\hline 2 & steady state & 24.0 & 47.3 & 27.0 & 1.8 & 0.0 \\
\hline 3 & steady state & 48.0 & 31.6 & 23.7 & 5.1 & 0.0 \\
\hline \multirow[t]{2}{*}{4} & initial conditions & 0 & 0.0 & 14.4 & 14.4 & 0.0 \\
\hline & $\begin{array}{l}\text { BHE-3 2U DN32 100m } \\
\text { smooth }\end{array}$ & TRT Time & Heat Power & Cooling Cycle & $\begin{array}{l}\text { Heating Cycle } \\
\text { (Inversed) }\end{array}$ & $\begin{array}{l}\text { Rejected Heat } \\
\text { TRT }\end{array}$ \\
\hline Step & Heat flow regime & $\mathrm{hr}$ & $\mathrm{W} / \mathrm{m}$ & $\mathrm{EST}^{\circ} \mathrm{C}$ & $\mathrm{EST}^{\circ} \mathrm{C}$ & $\mathrm{kWh}$ \\
\hline $1 \mathrm{a}$ & unsteady & 68.8 & 47.3 & 26.9 & 2.1 & 325.6 \\
\hline 1 & semi-steady state & 240.0 & 47.3 & 29.5 & -0.3 & - \\
\hline 2 & steady state & 23.7 & 35.5 & 25.2 & 4.0 & 0.0 \\
\hline 3 & steady state & 32.7 & 23.7 & 22.4 & 6.8 & 0.0 \\
\hline \multirow[t]{2}{*}{4} & initial conditions & 0 & 0.0 & 14.6 & 14.6 & 0.0 \\
\hline & $\begin{array}{l}\text { BHE-4 1U DN45 150m } \\
\text { ribbed }\end{array}$ & TRT Time & Heat Power & Cooling Cycle & $\begin{array}{l}\text { Heating Cycle } \\
\text { (Inversed) }\end{array}$ & $\begin{array}{l}\text { Rejected Heat } \\
\text { TRT }\end{array}$ \\
\hline Step & Heat flow regime & $\mathrm{hr}$ & $\mathrm{W} / \mathrm{m}$ & $\mathrm{EST}^{\circ} \mathrm{C}$ & $\mathrm{EST}^{\circ} \mathrm{C}$ & $\mathrm{kWh}$ \\
\hline $1 \mathrm{a}$ & unsteady & 93.1 & 39.9 & 25.9 & 5.0 & 557.1 \\
\hline 1 & semi-steady state & 240.0 & 39.9 & 27.4 & 3.6 & - \\
\hline 2 & steady state & 24.0 & 29.9 & 24.3 & 6.7 & 0.0 \\
\hline 3 & steady state & 48.0 & 19.9 & 21.6 & 9.4 & 0.0 \\
\hline 4 & initial conditions & 0 & 0.0 & 15.5 & 15.5 & 0.0 \\
\hline
\end{tabular}

tor. Therefore, different test times could lead to quite different results of thermal conductivities. Figure 8 shows an analysis of thermal conductivity transitory values with test duration between 18 and 72 hours. It can be seen that until 48 hours of the test had passed, the results could be very misleading, depending on the time of the test. After 48 hours, results are much more similar with smaller degree of error as the test runs towards 72 hours or more. Analysis of the relative standard error (RSE) shows that after 72 hours of the test, the error value is between 5 and $8 \%$, which gives high confidence in the obtained results.

Figure 9 presents results of the thermal response testing as well as synthetic curves for two additional steps used. For each of the four boreholes, simulation of the thermal response test was performed by using the FLS method and Equations 14-16, each for the corresponding power step. It is seen that synthetic data has a good fit with the recorded data for the first step. For steps no. 2 and no.3, heat power values were assumed as 0.75 and 0.50 of the heat powers used as an initial value for additional 24 and 48 hours respectively. Stabilization points of temperature change as a function of time are observed for each of the BHE. By obtaining thermogeological parameters from real in-site TRT, such as conductivity and resistance, synthetic TRT curves could be constructed for various heat pulses. Such step tests are essential to determine steady state heat extraction rates for an arbitrary specified minimum brine temperatures, for example $0^{\circ} \mathrm{C}$ as presented by the EN14511 norm.

Table 3 shows all of the collected data from the Thermal Response Step Test with stabilization values for each step as a function of heat rejection or extraction rate. Three steady-state points are extracted from Figure 8 for each of the BHE, for both the cooling and heating cycle, including initial conditions (the $4^{\text {th }}$ point) and used to obtain heat extraction rates. 


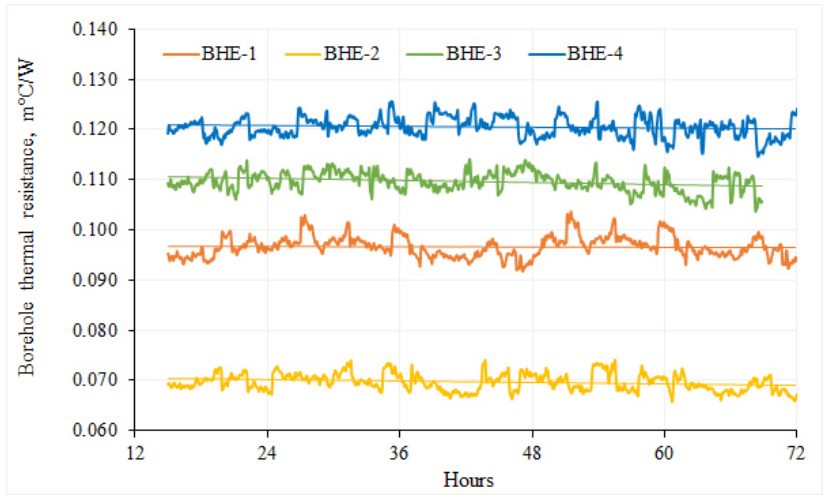

Figure 10: Equivalent transitory borehole thermal resistances determined by thermal response for four BHE configurations
Figure 10 shows the analysis of equivalent borehole resistance when semi-steady state heat flow occurs (between the $15^{\text {th }}$ and $72^{\text {nd }}$ hour). The calculation was performed following Gehlin's expression (Gehlin, 2002). The linear trend line states that the average equivalent borehole thermal resistance is $0.097 \mathrm{~m}^{\circ} \mathrm{C} / \mathrm{W}$ for BHE-1, $0.070 \mathrm{~m}^{\circ} \mathrm{C} / \mathrm{W}$ for $\mathrm{BHE}-2,0.110 \mathrm{~m}^{\circ} \mathrm{C} / \mathrm{W}$ for $\mathrm{BHE}-3$ and $0.120 \mathrm{~m}^{\circ} \mathrm{C} / \mathrm{W}$ for BHE-4. When comparing the borehole thermal resistance, it can be concluded that higher values occur in the case of the BHE-3, with a smooth pipe wall. Despite the thicker pipe wall in the case of the BHE-1, BHE-2 and BHE-4, the ribbed inside wall provides an enhanced turbulent fluid flow regime, thus increasing the heat transfer flow between the fluid and the plastic pipe wall, effectively reducing borehole thermal resistance.

Table 4: Thermal properties of ground and BHE according to performed TRT

\begin{tabular}{|c|c|c|c|c|}
\hline & \begin{tabular}{|c|}
$\begin{array}{c}\text { Thermal conductivity, } \\
\mathrm{W} / \mathbf{m}^{\circ} \mathrm{C}\end{array}$ \\
\end{tabular} & $\begin{array}{l}\text { Thermal borehole } \\
\text { resistance, }{ }^{\circ} \mathrm{C} \mathrm{m} / \mathrm{W}\end{array}$ & $\begin{array}{c}\text { Skin factor, } \\
-\end{array}$ & $\begin{array}{l}\text { Initial temperature drop due to } \\
\text { borehole resistances, } \Delta \mathrm{T}_{\text {skin }},{ }^{\circ} \mathrm{C}\end{array}$ \\
\hline BHE-1 2U DN32 50m ribbed & 2.06 & 0.097 & 1.24 & 4.9 \\
\hline BHE-2 2U DN40 75m ribbed & 2.00 & 0.070 & 0.88 & 4.4 \\
\hline BHE-3 2U DN32 100m smooth & 1.93 & 0.110 & 1.33 & 5.2 \\
\hline BHE-4 1U DN45 150m ribbed & 2.08 & 0.120 & 1.57 & 4.8 \\
\hline
\end{tabular}

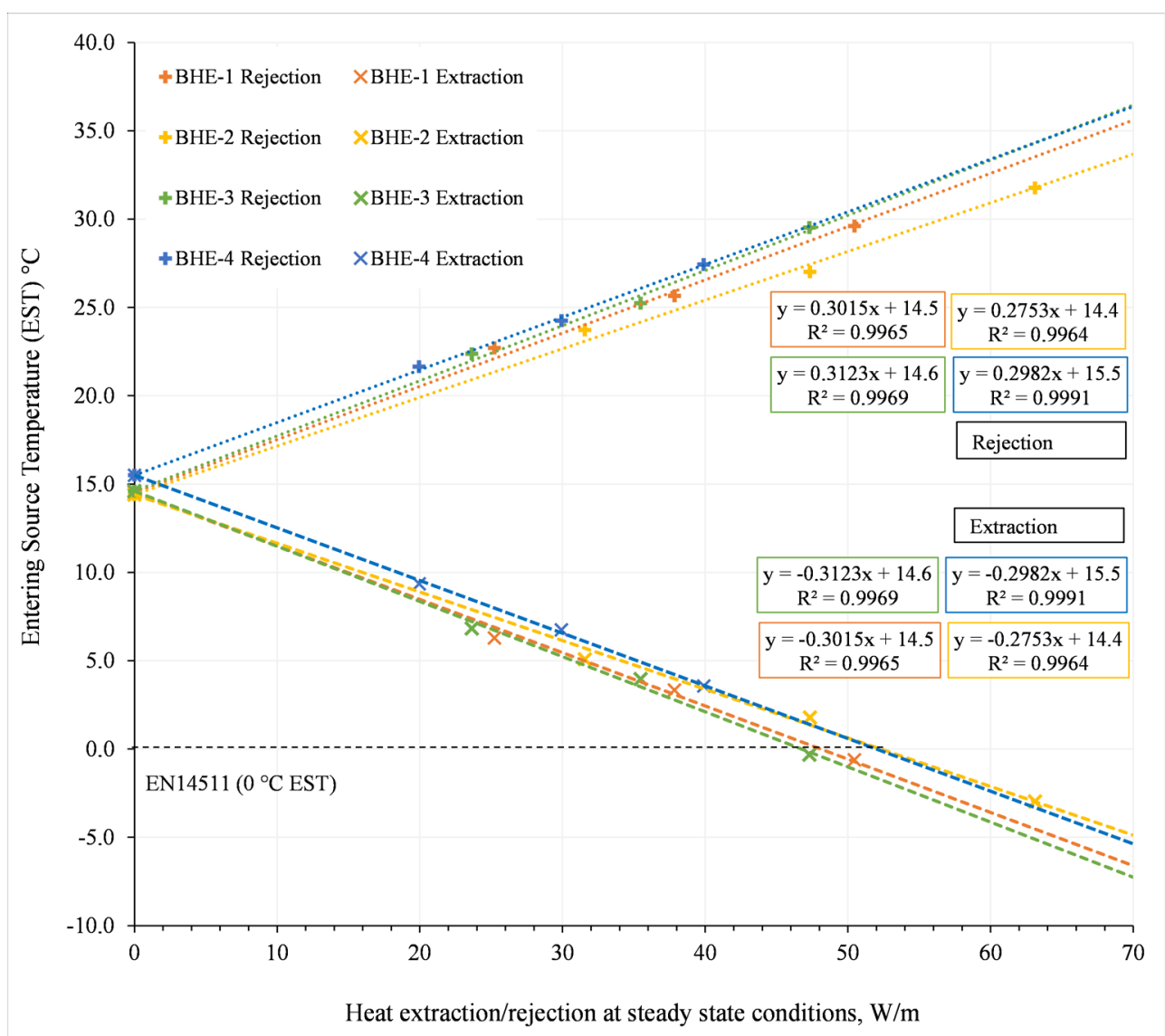

Figure 11: Determination of the rejection and extraction heat for four different pipe configurations 
Table 5: Heat extraction rates from four BHEs from relations given in Figure 11

\begin{tabular}{|c|c|c|c|c|}
\hline & $\begin{array}{l}\text { BHE-1 2U DN32 Ribbed, } \\
50 \mathrm{~m}\end{array}$ & $\begin{array}{l}\text { BHE-2 2U DN40 } \\
\text { Ribbed, } 75 \text { m }\end{array}$ & \begin{tabular}{|l|} 
BHE-3 2U DN32 \\
Smooth, $100 \mathrm{~m}$
\end{tabular} & $\begin{array}{l}\text { BHE-4 1U DN45 } \\
\text { Ribbed, } 150 \mathrm{~m}\end{array}$ \\
\hline $\begin{array}{l}\text { Extraction capacity, according to } \\
\left.\text { EN14511 (at } 0 /-3^{\circ} \mathrm{C}\right), \mathrm{W} / \mathrm{m}\end{array}$ & 48.1 & 52.3 & 46.7 & 51.9 \\
\hline Extraction capacity, per borehole, $\mathrm{kW}$ & 2.40 & 3.92 & 4.68 & 7.79 \\
\hline $\begin{array}{l}\text { Extraction capacity, peak conditions } \\
\left(\text { at }-4 /-7^{\circ} \mathrm{C}\right), \mathrm{W} / \mathrm{m}\end{array}$ & 60.3 & 66.6 & 58.3 & 64.3 \\
\hline $\begin{array}{l}\text { Extraction capacity, peak conditions } \\
\left(\text { at }-4 /-7^{\circ} \mathrm{C}\right) \text {, per borehole, } \mathrm{kW}\end{array}$ & 3.02 & 5.0 & 5.83 & 9.65 \\
\hline
\end{tabular}

Thermal conductivity, thermal resistance and related data for each of the tested borehole heat exchanger is presented by the following Table 4.

By taking the value of the steady state temperature in each of the steps as separate points, the heat rejection and extraction diagram is constructed as a function of the needed entering source temperature (EST) to the heat pump. The steady state temperatures at each point were calculated by using equations $14-16$, for the respective heat power step $(\mathrm{W} / \mathrm{m})$. This is done for each of the tested heat exchanger. The value of the temperature at the end of the time step and with respective heat extraction/rejection rate at the steady state conditions is plotted on the EST vs. Heat injection/extraction diagram (see Figure 11). The data is given in Table 3 - column 'cooling cycle' gives EST in the case of heat rejection (TRT or cooling application), while column 'heating cycle' gives the values of the EST in the case of heat extraction (heating application). Applying a linear trend line through four conditions from Figure 9/Table 3 for each $\mathrm{BH}$ exchanger gives an equation which represents an entering source temperature (EST) at the steady-state heat extraction rate for the analysed borehole heat exchanger.

Figure 11 shows that each initial (undisturbed) ground temperature is different, due to the influence of the geothermal gradient (Kurevija et al., 2014), which, for this location, is around $0.023^{\circ} \mathrm{C} / \mathrm{m}$ (Macenić et al., 2020). Deeper boreholes have a more favourable average temperature and commonly higher extraction rates due to larger $\Delta \mathrm{T}$ when compared to the set technical minimal entering source temperature to the heat pump, in peak conditions (specifically $0^{\circ} \mathrm{C}$ ). The fluid temperature in properly designed borehole heat exchangers should never fall below $0^{\circ} \mathrm{C}$ under peak load conditions, as set in the EN14511 norm for determining a reliable coefficient of performance of the heat pump. According to heat extraction/rejection steady-state equations given in Figure 11, the capacity for each of the tested BHE calculated and is given in Table $\mathbf{5}$.

According to the analysis of the ground thermal conductivity for all four exchanger systems, it can be seen that the results are within $10 \%$ of variation. Such differences can be explained primarily by the borehole depth, minor deviations in the power supply and weather conditions during measurement (interference from the surface), but also with ground heterogeneity and groundwater influence depending on well positions. Since the thermal conductivities of $2.06,2.00,1.93$ and $2.08 \mathrm{~W} / \mathrm{m}^{\circ} \mathrm{C}$ were measured on four BHEs, the mean value of 2.02 $\mathrm{W} / \mathrm{m}^{\circ} \mathrm{C}$ is determined. The extraction capacity of the borehole heat exchangers (375 $\mathrm{m}$ in total), according to the EN14511 standardized norm, is $2.40 \mathrm{~kW}(50 \mathrm{~m})+$ $3.92 \mathrm{~kW}(75 \mathrm{~m})+4.68 \mathrm{~kW}(100 \mathrm{~m})+7.79 \mathrm{~kW}(150 \mathrm{~m})=$ $18.8 \mathrm{~kW}$. The maximum extraction capacity (up to the propylene glycol freezing point, working condition -4/$\left.7^{\circ} \mathrm{C}\right)$ of the borehole heat exchangers $(375 \mathrm{~m}$ in total $)$ is $3.02 \mathrm{~kW}+5.00 \mathrm{~kW}+5.83 \mathrm{~kW}+9.65 \mathrm{~kW}=23.5 \mathrm{~kW}$. Given the best possible use of space, the positive impact of the geothermal gradient and higher initial borehole temperature, it is concluded that the $150 \mathrm{~m}$ deep borehole heat exchanger (1U DN45 with a ribbed inner wall) is the optimal choice for utilizing geothermal energy. The BHE-4 design was applied to an additional three boreholes drilled somewhat later. The total borehole heat exchanger length was then $900 \mathrm{~m}$, available to cover heating loads of Kindergarten Grdelin. The BHEs are yet to be integrated into the existing termo-technical system of the kindergarten.

\section{Discussion and Conclusion}

The objective of the HORIZON 2020 HAPPEN project is to demonstrate the possibilities for retrofitting energy inefficient buildings in the Mediterranean region, dealing with various solutions. One of the pilot sites was Kindergarten Grdelin, located in the city of Buzet, Croatia. Since the current termotechnical system is not sufficient in covering the heating and cooling loads of the building, a decision was made to subject it to adaptation. The adaptation was set to upscale the current geothermal circuit or the borehole heat exchanger field with additional borehole exchangers. In order to determine the optimal borehole heat exchanger type in the same geological environment, different drilling depths and completion of the boreholes were done and tested. Each of the four tested boreholes were of a different depth (50, 75,100 and $150 \mathrm{~m}$ ) and different geometrical properties 
(smooth or ribbed inner wall of the pipe and different diameters). Using the thermal response test, ground thermal properties were obtained for each of the tested BHEs. Eskilson's g-function calculations were performed in order to simulate the step TRT, thus obtaining data needed to determine extraction rates of different BHEs on the test site. The testing showed that the optimal BHE type was BHE-4, with $150 \mathrm{~m}$ of depth, $1 \mathrm{U}$ DN45 pipe with a ribbed inner wall, because of the positive impact of the geothermal gradient as seen from average initial temperature values. This layout was used to drill and complete three additional BHEs at the site, however the shallow geothermal system is yet to be connected to the existing thermo-technical system. Pipes with a ribbed inner wall show overall merit over the classic smooth inner wall, due to maintaining the turbulent fluid flow even at lower fluid flow rate and lower pressure drop. Extraction rates were calculated for the tested BHEs, and overall extraction capacity $(375 \mathrm{~m})$ was determined at $18.8 \mathrm{~kW}_{\mathrm{t}}$, with a maximum at 23.5 $\mathrm{kW}_{\mathrm{t}}$. BHE-5 which was not tested due to clogging issues, but was later cleaned and added to the BHE field as a working one.

A limitation of this study can be distinguished in the fact that one of the most important analysis parameters is borehole thermal resistance, where the obtained tested values are strongly related to the onsite work quality by the drilling company. The quality of the cementation procedure, proper insertion of heat exchanger and use of centralizers could lead to significantly lower values of thermal skin, as the effects of inlet/outlet short circuit interferences and filling gap between the pipe and cement diminishes. This variable is therefore impossible to accurately predict, as it can vary significantly.

Further research based on this presented work could be focused on determining the rate of influence of the geothermal gradient with increasing drilling depths. With market available heat exchangers up to $300 \mathrm{~m}$ in length (like DN45 SDR11 PN16) already in place, heat extraction rates defined in $\mathrm{W} / \mathrm{m}$ could be largely enhanced due to a favourable increase in temperature versus depth.

\section{Acknowledgment}

This research was done within the scope of the HORIZON 2020 project HAPPEN - Holistic AProach and Platform for the deep renovation of the med residential built Environment - Grant agreement ID:785072.

\section{Nomenclature}

$$
\begin{aligned}
& c-\text { specific heat capacity, }\left(\mathrm{J} / \mathrm{kg}^{\circ} \mathrm{C}\right) \\
& g-\text { Eskilson's g-function } \\
& e-\text { Euler number }(2.7183) \\
& E i \text { - exponential integral }
\end{aligned}
$$

$H$ - borehole depth (m)

$q^{\prime}$ - heat power per meter of a borehole, $(\mathrm{W} / \mathrm{m})$

$R_{b}^{\prime}$ - equivalent borehole thermal resistance, $\left({ }^{\circ} \mathrm{C} \mathrm{m} / \mathrm{W}\right)$

$r$ - radius, $(\mathrm{m}) /$ radial coordinate

$r_{b}$ - borehole radius, $(\mathrm{m})$

$t$ - time, (s)

$t_{p}-$ duration of the power step during semi-steady state, (s)

$t_{s}$ - time at which steady-state heat transfer occurs (s)

$T\left(r_{b}, t\right)$ - temperature in function of radius and time, $\left({ }^{\circ} \mathrm{C}\right)$

$T$ - temperature, $\left({ }^{\circ} \mathrm{C}\right)$

$T_{i}$ - initial borehole temperature, $\left({ }^{\circ} \mathrm{C}\right)$

$T_{i}-T_{p}$ - temperature difference between initial temperature and temperature at the end of the power step, $\left({ }^{\circ} \mathrm{C}\right)$

$s$ - skin factor, -

$x$ - exponential integral variable; TRT elapsed time

$y$ - borehole fluid temperature

$z$ - height axis

$\alpha$ - thermal diffusivity, $\left(\mathrm{m}^{2} / \mathrm{s}\right)$

$\phi$ - azimuthal coordinate

$\Delta T_{\text {skin }}$ - temperature drop/rise due to skin effect, $\left({ }^{\circ} \mathrm{C}\right)$

$\gamma$ - Euler's constant $(\gamma=0.5772)$

$\kappa$-slope of the line

$\lambda$ - thermal conductivity, $\left(\mathrm{W} / \mathrm{m}^{\circ} \mathrm{C}\right)$

$\rho$-density, $\left(\mathrm{kg} / \mathrm{m}^{3}\right)$

\section{References}

Acuña, J. (2010): Improvements of U-Pipe Borehole Heat Exchangers. Licenciate Thesis, KTH School of Industrial Engineering and Management, Stockholm, Sweden.

ASHRAE, 1995. Commercial/Institutional Ground-Source Heat Pump Engineering Manual. American Society of Heating, Refrigeration and Air-Conditioning Engineers, Inc., Atlanta, USA.

Bae, S.M., Nam, Y., Choi, J.M., Lee, K.H. and Choi, J.S. (2019): Analysis on thermal performance of ground heat exchanger according to design type based on thermal response test. Energies, 12, 4, 651. doi: https://doi.org/ 10.3390/en12040651

Bouhacina, B., Saim, R. and Oztop, H.F. (2015): Numerical investigation of a novel tube design for the geothermal borehole heat exchanger. Applied Thermal Engineering, 79, 153-162. doi: https://doi.org/10.1016/j.applthermaleng.2015.01.027

Carslaw, H.S. and Jaeger, J.C. (1959): Conduction of Heat in Solids. Clarendon Press: Oxford.

Chiasson, A.D. (2016): Geothermal Heat Pump and Heat Engine Systems: Theory and Practice. John Wiley \& Sons Ltd.: Hoboken.

Claesson, J. and Eskilson, P. (1987): Conductive Heat Extraction by a Deep Borehole. Analytical Studies. Department of Mathematical Physics, University of Lund: Lund, Sweden. 
Directive (EU) 2018/2001 of the European Parliament and of the Council of 11 December 2018 on the promotion of the use of energy from renewable sources. Official Journal of the European Union, 5, 82-209.

Eskilson, P. (1987): Thermal Analysis of Heat Extraction Boreholes. Ph.D. Thesis, University of Lund, Lund, Sweden.

Fourier, J. (1822): Theorie Analytique de la Chaleur, par M. Fourier. Chez Firmin Didot, Père et Fils, Paris, France.

Fang, L., Diao, N., Fang, Z., Zhu, K. and Zhang, W. (2017): Study on the efficiency of single and double U-tube heat exchangers. Procedia Engineering, 205, 4045-4051.

Gehlin, S. (2002): Thermal Response test: Method Development and Evaluation. Ph.D. Thesis, Lulea University of Technology, Lulea, Sweden.

Ingersoll, L.R. and Zobel, O.J. (1913): An Introduction to the Mathematical Theory of Heat Conduction. Ginn and Company: Boston.

Jahanbin, A. (2020): Thermal performance of the vertical ground heat exchanger with a novel elliptical single Utube. Geothermics, 86, 101804. doi: https://doi.org/10.1016 j.geothermics.2020.101804

Kapuralić, J., Posavec, K., Kurevija, T. and Macenić, M. (2018): Identification of river Sava temperature influence on groundwater temperature of the Zagreb and SamoborZaprešić aquifer as a part of shallow geothermal potential. Rudarsko-geološko-naftni zbornik (The Mining-Geological-Petroleum Engineering Bulletin), 33, 5, 59-69. doi: 10.17794/rgn.2018.5.6

Kappelmeyer, O. and Haenel, R., (1974). Geothermics with special reference to application. Gebrueder Borntraeger: Berlin.

Kurevija, T. and Vulin, D. (2010): Determining undisturbed ground temperature as part of shallow geothermal resources assessment. Rudarsko-geolosko-naftni zbornik (The Mining-Geological-Petroleum Engineering Bulletin), 22, 1, 27-36.

Kurevija, T., Vulin, D. and Krapec, V. (2012): Effect of borehole array geometry and thermal interferences on geothermal heat pump system. Energy Conversion and Management, 60, 134-142. doi: https://doi.org/10.1016/j.enconman.2012.02.012

Kurevija, T., Vulin, D. and Macenić, M. (2014): Impact of geothermal gradient on ground source heat pump system modeling. Rudarsko-Geolosko-Naftni Zbornik, 28, 1, 39.

Kurevija, T., Macenić, M. and Borović, S. (2017): Impact of grout thermal conductivity on the long-term efficiency of the ground-source heat pump system. Sustainable Cities and Society, 31, 1-11. doi: https://doi.org/10.1016/j.scs. 2017.02.009

Kurevija, T. and Strpić, K. (2018): Hydraulic and thermogeological design differences between two-loop vertical and inclined coaxial borehole heat exchangers. Renewable energy, 117, 314-323. doi: https://doi.org/10.1016/j.renene. 2017.10.077

Kurevija, T., Strpić, K. and Koščak-Kolin, S. (2018a): Applying petroleum the pressure buildup well test procedure on thermal response test-A novel method for analyzing temperature recovery period. Energies, 11, 2, 366. doi: https:// doi.org/10.3390/en11020366
Kurevija, T., Macenić, M. and Strpić, K. (2018b): Steady-state heat rejection rates for a coaxial borehole heat exchanger during passive and active cooling determined with the novel step thermal response test method. Rudarskogeološko-naftni zbornik (The Mining-Geological-Petroleum Engineering Bulletin), 33, 2, 61-71. doi: 10.17794/ rgn.2018.2.6

Kurevija, T., Kalantar, A., Macenić, M. and Hranić, J. (2019): Investigation of Steady-State Heat Extraction Rates for Different Borehole Heat Exchanger Configurations from the Aspect of Implementation of New TurboCollector ${ }^{\mathrm{TM}}$ Pipe System Design. Energies, 12, 8, 1504. doi: doi: 10.3390/en12081504

Lee, J. (1982): Well Testing. Society of Petroleum Engineers of AIME, SPE, Richardson, USA.

Li, R., Ooka, R. and Shukuya, M. (2014): Theoretical analysis on ground source heat pump and air source heat pump systems by the concepts of cool and warm exergy. Energy and Buildings, 75, 447-455. doi: https://doi.org/10.1016/j.enbuild.2014.02.019

Lund, J.W. and Toth, A.N. (2020): Direct Utilization of geothermal energy 2020 Worldwide review. Geothermics, 90 , p.101915. doi: https://doi.org/10.1016/j.geothermics.2020. 101915

Macenić, M., Kurevija, T. and Strpić, K. (2018): Systematic review of research and utilization of shallow geothermal energy in Croatia. Rudarsko-geološko-naftni zbornik (The Mining-Geological-Petroleum Engineering Bulletin), 33, 5, 37-46. doi: 10.17794/rgn.2018.5.4

Macenić, M., Kurevija, T. and Medved, I. (2020): Novel geothermal gradient map of the Croatian part of the Pannonian Basin System based on data interpretation from 154 deep exploration wells. Renewable and Sustainable Energy Reviews, 132, p.110069. doi: https://doi.org/10.1016/j.rser. 2020.110069

Matthews, C.S. and Russell, D.G. (1967): Pressure Buildup and Flow Tests in Wells; Society of Petroleum Engineers of AIME, Dallas, USA.

Ozgener, L., Hepbasli, A. and Dincer, I. (2007). Exergy analysis of two geothermal district heating systems for building applications. Energy Conversion and Management, 48, 4, 1185-1192. doi: https://doi.org/10.1016/j.enconman.2006. 10.003

Serageldin, A.A., Sakata, Y., Katsura, T. and Nagano, K. (2020): Performance enhancement of borehole ground source heat pump using single U-tube heat exchanger with a novel oval cross-section (SUO) and a novel spacer. Sustainable Energy Technologies and Assessments, 42, p.100805. doi: https://doi.org/10.1016/j.seta.2020.100805

The Geological Survey of Slovenia. Basic geological map of SFRJ-Trst. Belgrade, Serbia, 1969.

Zarrella, A., Emmi, G. and De Carli, M. (2017): A simulationbased analysis of variable flow pumping in ground source heat pump systems with different types of borehole heat exchangers: A case study. Energy Conversion and Management, 131, 135-150. doi: https://doi.org/10.1016/j.enconman.2016.10.061 


\section{SAŽETAK}

\section{Određivanje prinosa bušotinskih izmjenjivača različitih geometrijskih karakteristika u istome geološkom okruženju - Rezultati pilot-projekta HAPPEN - HORIZON 2020}

Zgrada dječjega vrtića Grdelin, smještena u gradu Buzetu, Istarska županija, odabrana je unutar HORIZON 2020 HAPPEN projekta za obnovu i dopunu termotehničkoga sustava grijanja i hlađenja. Postojeći sustav bušotinskih izmjenjivača nije dovoljan da pokrije potrebe za toplinskom energijom te je zaključeno da je potrebna izrada dodatnih bušotinskih izmjenjivača topline. Da bi se odredio optimalan tip bušotinskoga izmjenjivača u istome geološkom okruženju, izrađene su 4 bušotine različitih dubina te su opremljene bušotinskim izmjenjivačima različitih geometrijskih karakteristika: BHE-1 (50 m, 2U DN32 žljebasta), BHE-2 (75 m, 2U DN40 žljebasta), BHE-3 (10o m, 2U DN32 glatka) i BHE-4 (150 m, 1U DN45 žljebasta). Test toplinskoga odaziva (TRT) izveden je na svim četirima bušotinama te su određena toplinska svojstva tla. Nadalje, simulacijom toplinskoga step-testa dobiveni su temperaturni odazivi pomoću kojih su određeni prinosi za pojedini bušotinski izmjenjivač. Zaključeno je da je BHE-4 izmjenjivač ( $150 \mathrm{~m}, 1 \mathrm{U}$ DN45 žljebasta), s obzirom na pozitivan utjecaj geotermalnoga gradijenta, više početne, statičke, temperature tla i pozitivnoga utjecaja žljebaste cijevi, onaj koji se pokazao kao optimalan izbor na lokaciji. Prinos svih testiranih bušotinskih izmjenjivača prema normi EN14511 i ulaznoj temperaturi o ${ }^{\circ} \mathrm{C}$ iznosi $18,8 \mathrm{~kW}_{\mathrm{t}}$ te $23,5 \mathrm{~kW}_{\mathrm{t}}$ pri vršnim uvjetima.

\section{Ključne riječi:}

bušotinski izmjenjivači topline, geološko okruženje, geotermalni gradijent, određivanje toplinskoga prinosa

\section{Author's contribution}

Tomislav Kurevija (Assoc. Prof., PhD) lead the research, conducted TRT field measurements, processed TRT data, performed calculations in Excel, and wrote the paper. Marija Macenić (PhD) compiled the Methods section, helped with data interpretation and wrote text. Tea Sabolić (univ. bacc. ing. petrol.) helped with data interpretation, compiled results and wrote the paper. Dalibor Jovanović helped with the field work and wrote text. 